\title{
CHAPTER 82
}

\section{PREDICTED FLUSHING TIMES AND POLLUTION DISTRIBUTION IN THE COLUMBIA RIVER ESTUARY}

\author{
Victor T. Neal \\ Assistant Professor \\ Department of Oceanography \\ Oregon State University, Corvallis, Oregon
}

\begin{abstract}
The observed salinity distribution in the Columbia River Estuary is used to predict the flushing times for various river discharge rates, varying tidal ranges, and varying salinity intrusions. Both the modified tidal prism method and the fraction of fresh water method are used, and the results are compared. The latter method predicts shorter flushing times, while both methods vary in a similar manner with changing river discharge and changing salinity intrusion. Both methods predict a relatively short flushing time for the estuary.

The observed salinity distributions under varying conditions are also used to predict the distribution of conservative and non-conservative pollutants. In this case the fraction of fresh water method and the diffusion equation are used. In general, the fraction of fresh water method predicts higher concentrations. When the lower estuary is divided into two channels, the two methods give quite different results. The diffusion equation method predicts a peak concentration upstream from the outfall rather than at the outfall, when the outfall location is a rbitrarily placed at certain locations.
\end{abstract}

\section{INTRODUCTION}

\section{THE RIVER}

The largest river on the Pacific Coast of North America, the Columbia, begins in Columbia Lake, Britısh Columbia, Canada, and flows some 1, 200 miles before discharging into the Pacific Ocean near Astoria, Oregon. The main tributaries to the system are the Okanogan, Kootenai, Clark Fork, Snake, and Willamette Rivers. The drainage area of this system amounts to nearly 259,000 square miles, most of 1t between the Rocky Mountains and the Cascade Mountains. A large portion of this rugged area is made up of lava flows and is known as the Columbia Plateau.

The Columbia is the most important inland wate rway in the Pacific Northwest. The river is navigable from its mouth to Vancouver, Washington, and a good volume of ocean traffic continues up the Willamette River to Portland, Oregon. Barge traffic now extends upstream as far as Pasco, Washington, by means of lock systems in the many large dams that have been built on the river. 


\section{THE ESTUARY}

The width of the river changes from less than one mile at a distance of 50 miles upstream to approximately nine miles at a distance of 20 miles from the mouth (Figure 1). Th1s section has many winding channels which are separated by low islands, bars and shoals. The depths vary from shoal areas to natural depths of over 100 feet below mean lower low water. The ship channel is presently maintained at a depth of 35 feet.

The section from just inside the mouth to the area opposite Tongue Point consists of two main channels (Figure 2). The channel on the Oregon side is the dredged ship channel; the channel on the Washington side is not dredged at present. The channels, although not completely distinct, are separated by several low islands, bars and shoals. The effect of the two channel system on circulation is important since the north channel carries the greater flood current, but the weaker ebb current.

The tide is the mixed semi-diurnal type typical of the west coast of North America. The mean range at the mouth is 6.5 feet while the range from mean lower low water to mean higher high water $1 \mathrm{~s} 8.5$ feet. The tide travels up the estuary like a progressive wave and may be noticed upstream as far as 140 miles during low river stages.

Fresh water flow through the estuary varies seasonally. Even though the entire region is characterized by heavier precipitation in the winter than in the summer, the peak flows usually occur during the months of May through July due to melting snows in the high mountains. Low flows usually occur during the months of September through March, however, freshets may occur during this time. The maximum discharge of record, during the flood of June, 1894, was estimated at $1,200,000 \mathrm{cfs}$, while the extreme low river flow has been estimated at $65,000 \mathrm{cfs}$ (Hicks on and Rodolf, 1951). The freshet flows average nearly $660,000 \mathrm{cfs}$. Th1s wide range of river flow is expected to be controlled by dams which will hold the maximum flow to $600,000 \mathrm{cfs}$ and increase the minimum to $150,000 \mathrm{cfs}$ (Lockett, 1963).

Salinity intrusion varies with the stage of tide and with the river flow. During low river flow and lower low water the salinity intrusion is less than 15 nautical miles but higher high water may increase this to nearly 20 nautical miles. When the river flow is high the intrusion may vary between a maximum at higher high water of 13 nautical miles and a minimum at low tide stages of less than five nautical miles.

Salinity data from many sources (O'Brien, 1952, Burt and McAlister, 1959, Corps of Engineers Report, 1960) were compiled, compared, and used in classifying the estuary and predicting flushing times and pollution distribution. The classification of the estuary is quite complex since the degree of mixing varies from one part of the estuary to another and varies 
with tidal stage and river flow. During high river flow and high tide the estuary is partially mixed at the mouth, changing gradually to a stratified system upstream. As the tide ebbs, the estuary becomes stratified nearly to the mouth. Low river discharge and high tide produce a wellmixed situation near the mouth, gradually changing to a partially mixed system upstream. As the tide ebbs, the estuary becomes partially mixed as far downstream as the mouth.

Small horizontal salinity gradients are found at the entrance during periods of maximum salinity intrusion. The salinity on the south side becomes higher than that on the north. However, the difference is not more than three parts per thousand. The Coriolis effect apparently does not control the water movement inside the mouth of the estuary since the greater flood velocities are found on the north side and the greater ebb velocities on the south side. This effect is probably produced by the orientation of the two channels in the estuary (Figure 2).

\section{PREDICTION OF FLUSHING TIMES}

\section{METHODS}

The modified tidal prism method. This method, presented by Ketchum (1951), predicts the flushing time for an estuary when the entire pollution load is brought into the estuary by the river. Therefore, the amount of river water within a given segment is an indicator of the accumulation of pollutants in that segment. The estuary is segmented according to the scheme which follows. The inner end is taken as that section above which the volume required to raise the level of the water from low to high water is equal to the volume contributed by the river during a tidal cycle. The water above this section 1s, therefore, entirely from the river flow and is fresh water. Each segment down the estuary is defined so that the high tide volume in the landward one is equal to the low tide volume in the adjacent seaward one.

It is assumed that the water within a segment is completely mixed at high tide. Therefore, the proportion of polluted water removed on the ebb tide (the exchange ratio $r_{n}$ for that segment) is equal to the local intertidal volume divided by the high tide volume of the segment, or expressed in symbols,

$$
r_{n}=\frac{P_{n}}{P_{n}+V_{n}}
$$

The river water found in each segment is a mixture of river water accumulated during several tidal cycles. If it is assumed that the river flow is constant during the period in question, then the total volume of river water, $E_{n}$, accumulated within any segment of the estuary at high tide can be found by the equation

$$
E_{\mathrm{n}}=\frac{\mathrm{Q}}{\mathrm{r}_{\mathrm{n}}}
$$

where $Q$ represents the volume of river flow per tidal cycle. 
The average number of indal cycles needed for the river water to move through a given segment, or in other words, the flushing time for that segment, is equal to $1 / \mathrm{r}_{\mathrm{n}}$ since

$$
1 / r_{n}=\frac{E_{n}}{Q}
$$

Then the flushing time for the entıre estuary is the sum of the flushing times for the individual segments.

This method can be modified to include stratified estuaries. How ever, such a modification produces an increased flushing rate, and was not used in the prediction.

The fraction of fresh wate $\mathbf{r}$ method. The flushing time can be predicted by using the known distribution of salinity or fresh water in the estuary. The fraction of fresh water, $f$, in this method is determined from the equation

$$
f=\frac{\left(S_{s}-S_{e}\right)}{S_{s}}
$$

in which $S_{S}$ is the salinity of the sea water entering the estuary and $S$ is the salinity of the water in a given segment of the estuary. When the fraction of fresh water has been determined, the volume of fresh water can be determined. The flushing time is then given by the time necessary for the river flow to supply the fresh water volume. If this is done for each segment of the estuary, the flushing time for the estuary is the sum of flushing times for the segments.

\section{RESULTS}

The modified tidal prism method. In order to use this method the cross-sectional areas, low tide volumes, and high tide volumes were measured or computed from the U. S. Coast and Geodetic Survey Charts No. 6151 and No. 6152. The estuary was sectioned at intervals of one nautical mile, with intermediate section values being obtained by inter polation as required. River flows were taken from the ranges given by the Corps of Engineers (Vol 4, 1960) or Hicks on and Rodolf (1951).

The modified tidal prism method is best suited to well-mixed estuaries that are characterized by a standing tide wave. Although the Columbia Estuary is not consistently well-mixed, the greatest pollution problems and poorest flushing times are most likely to occur when it most closely approaches the well-mixed condition. Therefore, the modified tidal prism method was used. The tide in the estuary, even though it shows pronounced progressive wave characteristics, 
may be approximated by a standing wave of nearly uniform range over the distance of maximum salinity intrusion without excessive error if a suitable average tidal range is chosen.

Table I gives the results obtained by the modified tidal pris $m$ method. Factors that are known to be variable in the estuary-tide range, salinity intrusion, and river flow--were assigned values commensurate with observed values. In all cases the seaward end of the zero segment was chosen to coincide with or exceed the limit of maximum salinity intrusion. The maximum salinity intrusion of 22 nautical miles is not normally expected but was used to determine the effect if significant amounts of fresh water are diverted from the estuary. The tidal range of 6.5 feet is probably more reasonable than 8. 0 feet but the use of the two ranges shows the effect of tidal range on the flushing times.

When the river flow was taken as high as $2,490 \times 10^{7} \mathrm{ft}^{3} /$ tidal cycle (flood stage or near flood stage) it was not feasible to use this method. River flows of this magnitude force the maximum salinity intrusion so far toward the mouth that proper segmentation of the estuary is impractical.

The fraction of fresh water method. The results obtained by this method are given in Table 2. The flushing times listed are the sums of the flushing times for one nautical mile segments.

\section{DISCUSSION}

The flushing times predicted by the modified tidal prism method varied from a maximum of nearly ten to less than five tidal cycles. If the method were modified to allow for a stratified estuary, even shorter flushing times would result. Variation in tidal range causes only a slight change in flushing time, never greater than one tidal cycle. Since the modified tidal prism method could not be used for very high river flows, it can only be inferred by extrapolation that the flushing time would probably drop to one day or less during such times. The change in maximum salinity intrusion from 19 to 22 nautical miles increased the flushing time less than one tidal cycle.

The fraction of fresh water method gave a range of flushing times from nearly five tidal cycles to less than one, generally from one to two days shorter than the times predicted by the modified tidal prism method. A graphical comparis on of the results by the two methods 1s shown in Figure 3. The slopes of the curves are nearly the same, indicating that variations in river flow have similar effects on the methods. Since the modified tidal prism method predicts longer flushing times, this method would give safer predictions and should probably be used, even though it is somewhat more complicated. In order to determine which method is more nearly correct, it would be necessary to use more expensive techniques, such as dye studies, model studies, etc. 


\section{PREDICTION OF POLLUTION DISTRIBUTION}

\section{METHODS}

The fraction of fresh water. The known or calculated fraction of fresh water can be used to predict pollution distribution in an estuary by assuming the pollutant, introduced at a constant rate, will be trans ported downstream with the river water and upstream with the sea water. Under steady state conditions the pollution distribution will be maintalned. According to Ketchum (1955) the average concentration, $\mathrm{C}_{\mathrm{n}}$, at any position downstream may be determined by the equation,

$$
C_{n}=C_{0}\left(\frac{f_{n}}{f_{0}}\right) \text {, }
$$

where $C_{o}$ is the concentration at the outfall, $f_{n}$ is the fraction of fresh wate $r$ at the position, and $f_{o}$ is the fraction of fresh water at the outfall. Similarly the average concentration at any point upstream, $C_{n}$, is given by

$$
C_{n}=c_{0}\left(\frac{s_{n}}{s_{s}}\right) \text {, }
$$

where $S_{S}$ stands for the average salinity of the ocean water and $S_{n}$ is the average salinity at the point in question.

The diffusion equation. The diffusion equation used by Stommel (1953) is suitable for prediction of the pollutant distribution in a well-mixed estuary. The actual distribution of river water is used to determine the turbulent diffusion coefficients at various places in the estuary. The se coefficients may then be used to predict the concentration of pollution at given points.

The net seaward flux of a pollutant across any given section is taken as the sum of the advective flux and the turbulent flux, or

$$
F(x)=R c-A D \frac{d c}{d x}
$$

where $R$ is the river discharge, $x$ is the distance along the longitudinal axis, $c$ is the average concentration of pollutant, $A$ is the cross sectional area at that section, and $D$ is the turbulent eddy diffusivity. The steady state equation for the general case involves $T$, the time required for the concentration of a non-conservative pollutant to decay from $c$ (concentration at the outfall) to $c_{o} / e$, where $e$ is the base of natural logarithms, and is written,

$$
\frac{d}{d x}\left(R c-A D \frac{d c}{d x}\right)+\frac{A c}{T}=0
$$


If $f$, the fraction of fresh water, is substituted for $c$ in equation (7), and $F(x)$ is given by the river flow, the equation becomes

$$
D=\frac{R(f-1)}{A d f / d x} .
$$

Equation (8) can be expressed in finite difference form. When measured and calculated values are substituted, a series of equations may be written. These equations may be solved by the relaxation method used by Stommel (1953) or by elimination techniques.

\section{RESULTS}

Fraction of fresh water method. Pollution distribution predicted by this method is shown in Figure 4. The concentration is expressed in percent of that at the outfall. Outfall locations were chosen arbitrarily for comparison purposes. At high river flow the salt does not penetrate as far as Tongue Point in significant amounts. Therefore, this outfall location was used only to represent low river flow conditions.

Diffusion equation method. Outfall locations similar to those used in the fraction of fresh water method were used. However, calculations were made using non-conservative as well as conservative pollutants. The rate of pollutant supply was arbitrarily selected as 10 pounds per second, while the maximum salinity intrusion was assumed to be 19 nautical miles. The tide range was taken as 6.5 feet. The results are shown in Figure 5. Cross sections taken at intervals of one-half nautical mile (instead of the customary one nautical mile) were also used but no significant changes in results were observed.

Since the estuary has two rather distinct channels an attempt was made to treat the pollution distribution in each channel separately. The flow was divided between the north and south channels by means of the Manning formula; then varıous outfall locations were chosen for each side of the river. In this calculation, the distribution was calculated by both the fraction of fresh water method and the diffusion equation. The results for the north channel are shown graphically in Figure 6 while the results for the south channel are given in Figure 7.

\section{DISC USSION}

The two methods used predicted the same general distribution of pollution for the river, except when the estuary was treated as two separate channels' (Figures 6 and 7). In this case not only different distribution patterns but also different concentrations were predicted by the two methods. In the north channel, where the flood currents are stronger, the diffusion equation predicted the peak concentration upstream from the outfall. In the south channel a somewhat irregular 
distribution was predicted by the diffusion equation while both methods predicted peak concentrations at the outfalls. The fraction of fresh water method predicted higher concentrations for the south channel but lower concentrations for the north channel than the othe $r$ method.

The distribution of non-conservative pollutants appears to be similar to the conservative distribution, although the concentration of the former would be somewhat less.

Of the two methods, the fraction of fresh water method is far simpler to use but it appears that it does not respond readily to variations in channel flow. The diffusion equation is, therefore, considered more reliable.

In the treatment of the separate channels, the observed salinity values used were not very plentıful. In a few cases values had to be interpolated or extrapolated from known values. The complete distribution of salinity by channels needs to be studied more thoroughly so that the results of this study may be evaluated more carefully.

\section{CONCLUSIONS}

In this study the effect of pollution and the type of pollutants we re not considered. Furthermore the addition of pollutants simultaneously at more than one outfall was not considered. Except in the case of the north and south channel locations, the resulting distribution could be calculated by adding the individual curves.

The reasons for the differences in concentration predicted by the two methods are not apparent. Further study is necessary to determine them. The effect of two channel flow also needs further study to determine where large concentrations of pollutants are likely to accumulate.

Organic pollutants generally lower the available dissolved oxygen in the system. During the times of the most severe pollution problems, low river flow and high tide, another phenomenon may occur in this region - upwelling. Upwelled waters are lower in oxygen than normal surface water of the ocean, and during high tide this low oxygen water would penetrate further into the estuary. The net result could be a severe lowering of the oxygen avallable in the water. This problem needs further study.

The expected increase in manufacturing in this region and the accompanying increase in population pressures are cause for concern about the pollution of this estuary. Already we have seen that the large dams are expected to produce a more stabilized flow in the river and thus will change the flushing capacity of the estuary. The deepening 
of the ship channel to accommodate the expected increase in shipping will also produce changes in the flushing capacity as well as in the pollution distribution within the estuary. Proposals to divert large volumes of water from the river are being discussed. Such diversion would cause a serious reduction in the flushing capability of the estuary.

The expected growth in this region demands that the proposed uses of a river of such importance be planned well in advance so that pollution does not become an insurmountable problem. Histories of certain rivers on the east coast clearly show that once pollution has been allowed to become severe, it is extremely difficult to reduce it, and seemingly impossible to eliminate it.

\section{REFERENCES}

Burt, Wayne V. and McAlister, Bruce (1959). Recent studies in the hydrography of Oregon estuaries: Research Briefs of the Fish Commission of Oregon, vol. 7, pp. 14-27.

Hickson, R. E. and Rodolf, F. W. (1951). History of the Columbia River jetties: Proceedings of the First Conference on Coastal Engineering, pp. 283-298.

Ketchum, Bostwick (1951). The exchanges of fresh and salt waters in tidal estuaries: Journal of Marine Research, vol. 10, pp. $18-38$.

Ketchum, Bostwick (1955). Distribution of coliform bacteria and other pollutants in tidal estuaries: Sewage and Industrial Wastes, vol. 27, pp. 1288-1296.

Lockett, John B. (1963). Phenomena affecting 1mprovement of the lower Columbia estuary and entrance: Proceedings of the Eighth Conference on Coastal Engineering, pp. 695-755.

O'Brien, Morrough P. (1952). Salinity currents in estuaries: Trans. Amer. Geophys. Union, vol. 33, pp. 520-522.

Stommel, Henry (1953). Computation of pollution in a vertically mixed estuary: Sewage and Industrial Wastes, vol. 25, pp. 1065-1071.

U.S. Corps of Engineers (1960). Interim report on 1959 current measurement program Columbia River at mouth Oregon and Washington: 4 volumes, Portland, Oregon. 


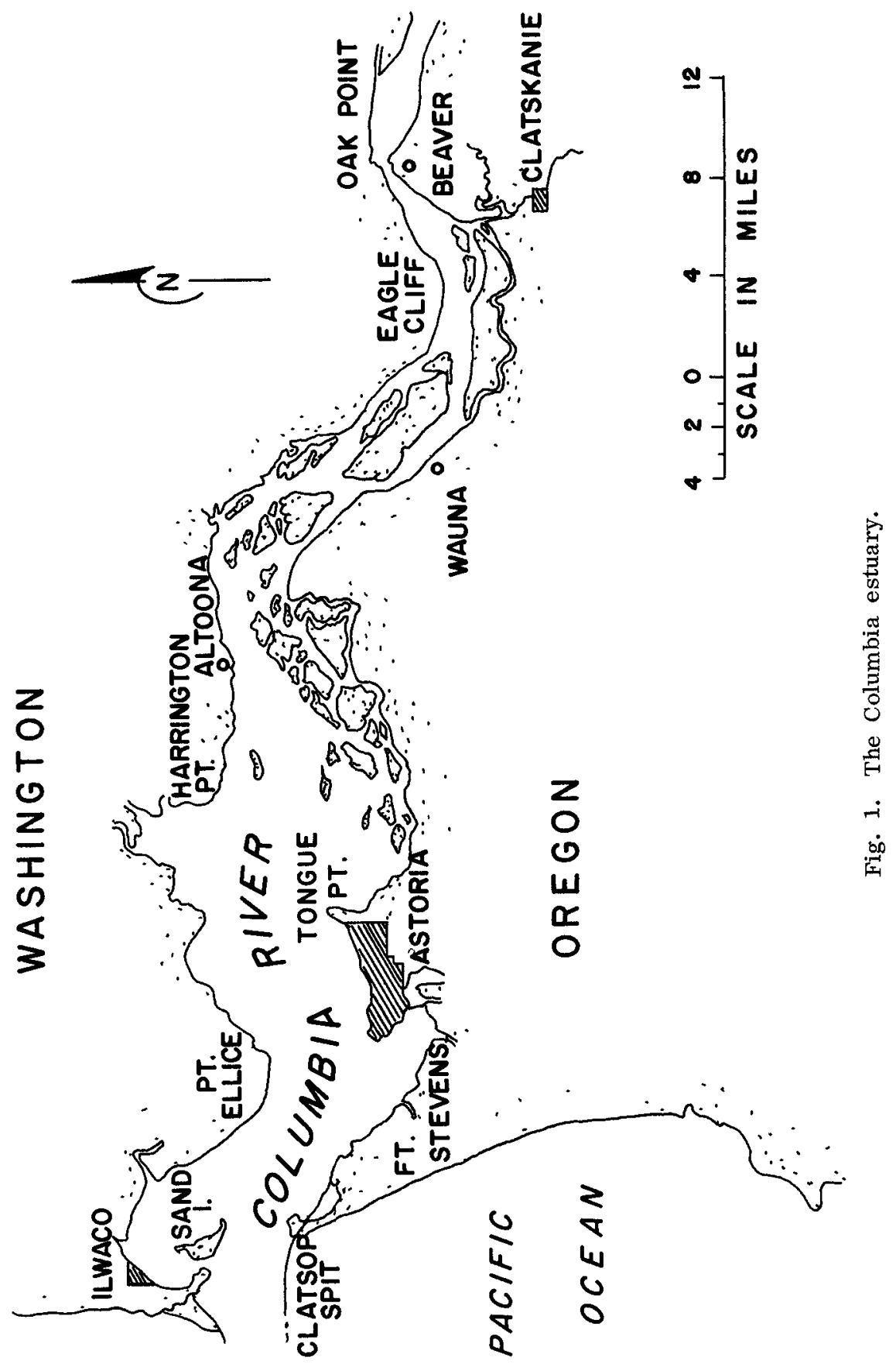




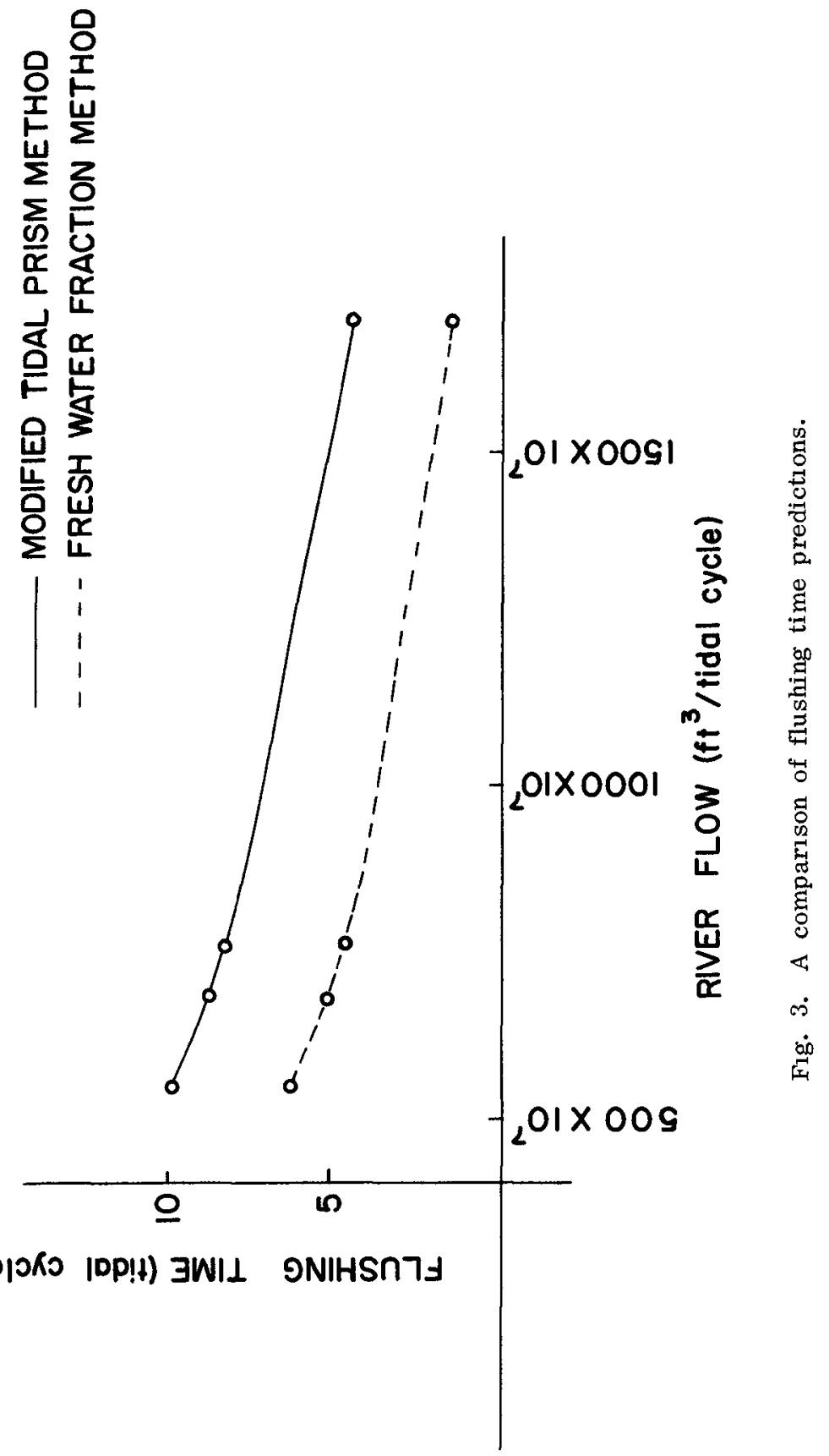




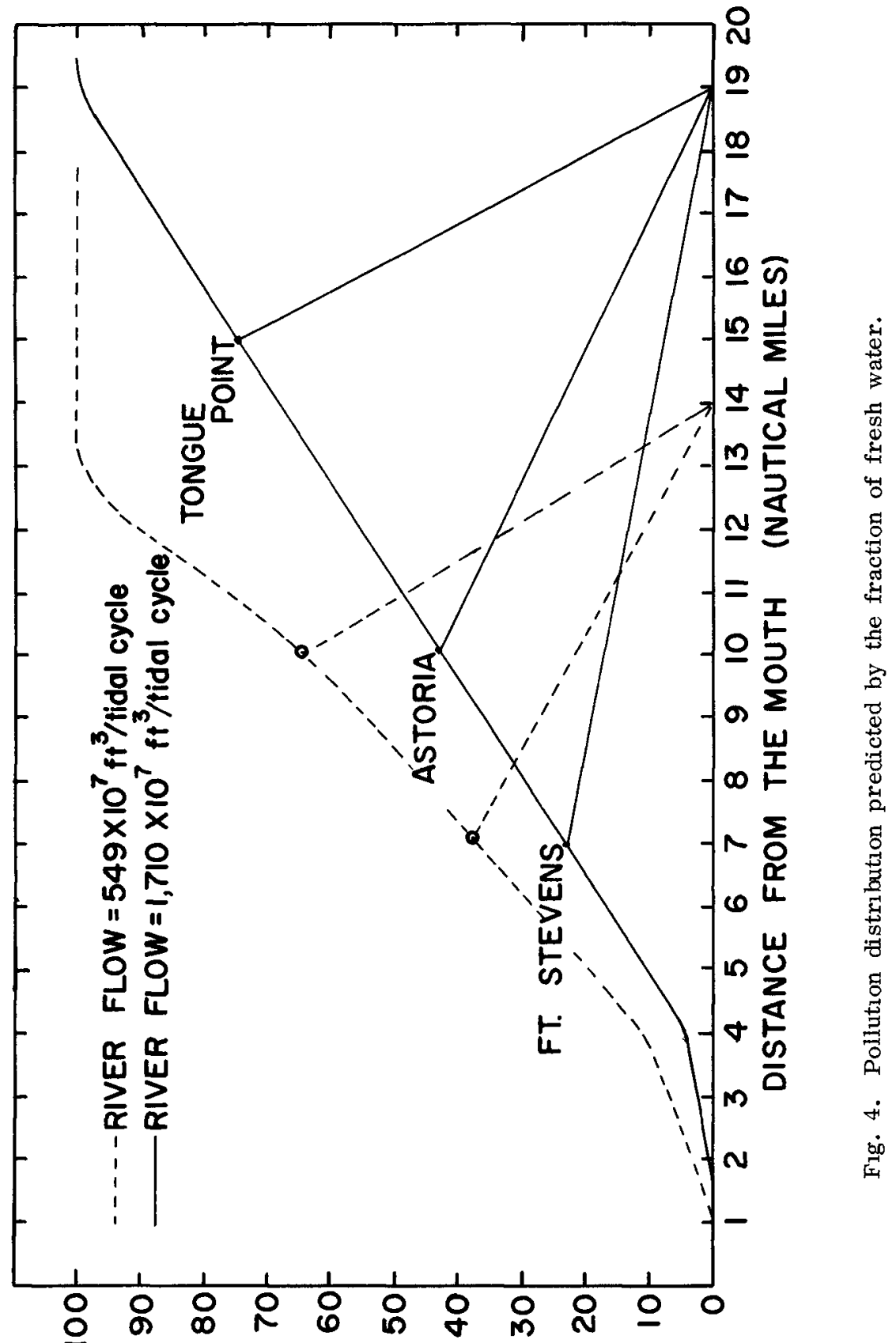

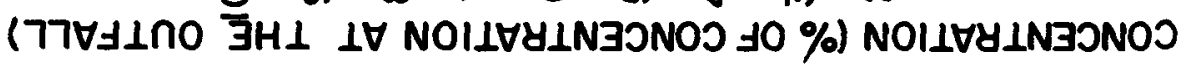




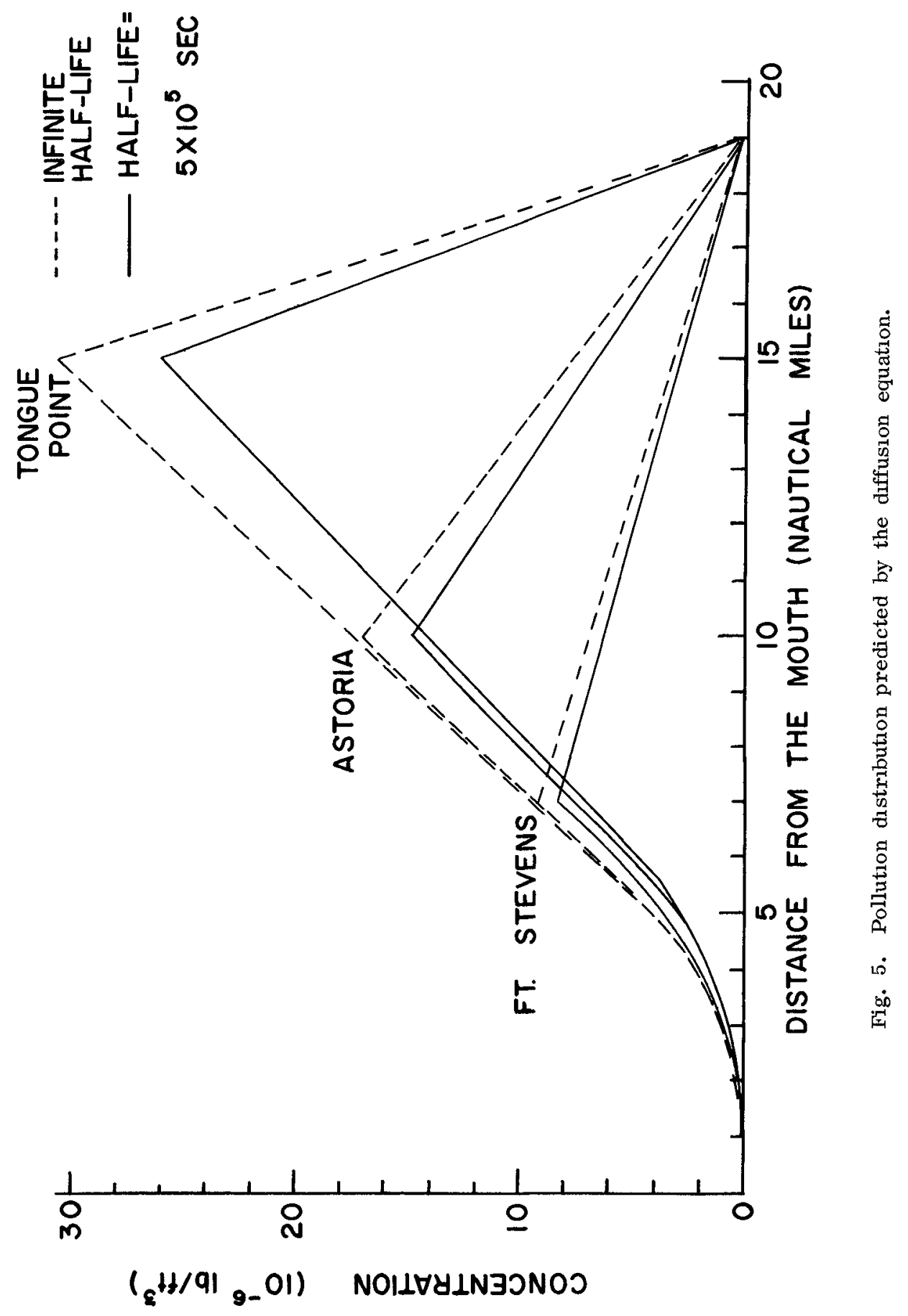




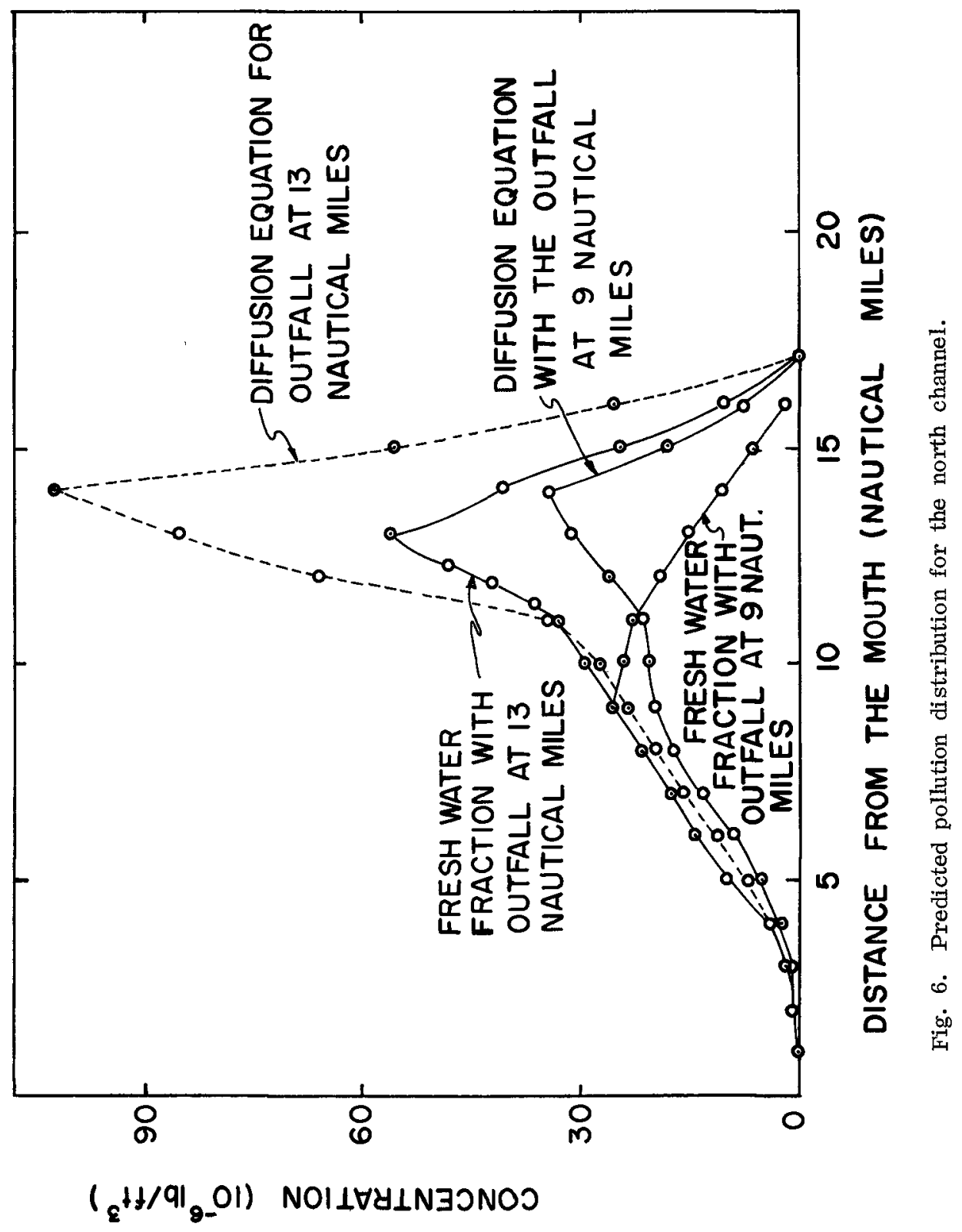




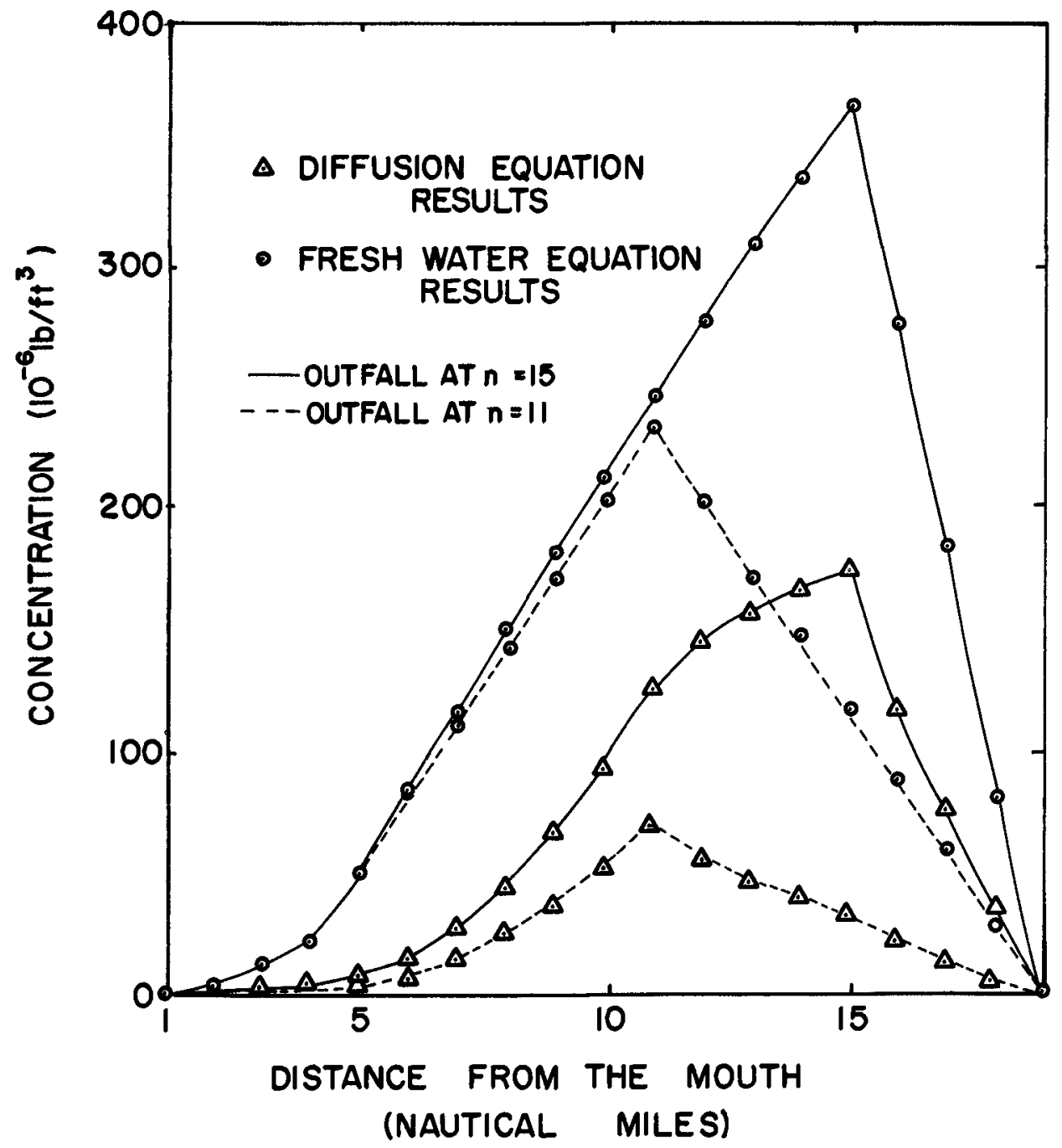

Fig. 7. Predicted pollution distribution for the south channel. 
Table 1. Flushing times predicted by the modified tidal prism method.

SUMMARY OF RESULTS OBTAINED BY THE MODIFIED

TIDAL PRISM METHOD FOR VARIOUS COMBINATIONS

OF RIVER FLOW, SALINITY INTRUSION, TIDAL RANGE, AND OCEAN SALINITY.

\begin{tabular}{lccc}
\hline $\begin{array}{l}\text { RIVER FLOW } \\
(\mathrm{ft} / \mathrm{fidal} \text { cycle) }\end{array}$ & $\begin{array}{c}\text { TIDAL RANGE } \\
(\mathrm{feet})\end{array}$ & $\begin{array}{c}\text { MAXIMUM } \\
\text { SALINITY } \\
\text { INTRUSION } \\
\text { (nautical miles) }\end{array}$ & $\begin{array}{c}\text { TOTAL } \\
\text { FLUSHING } \\
\text { TIME } \\
\text { (tidal cycis }\end{array}$ \\
\hline $549 \times 10^{7}$ & 6.5 & 19.0 & 900 \\
$549 \times 10^{7}$ & 6.5 & 220 & 991 \\
$549 \times 10^{7}$ & 8.0 & 19.0 & 9.00 \\
$549 \times 10^{7}$ & 8.0 & 22.0 & 9.12 \\
$684 \times 10^{7}$ & 6.5 & 22.0 & 8.59 \\
$684 \times 10^{7}$ & 8.0 & 22.0 & 8.66 \\
$755 \times 10^{7}$ & 6.5 & 19.0 & 8.23 \\
$755 \times 10^{7}$ & 8.0 & 19.0 & 7.78 \\
$1710 \times 10^{7}$ & 6.5 & 12.0 & 4.40 \\
$1710 \times 10^{7}$ & 8.0 & 14.0 & 4.28
\end{tabular}


Table 2. Flushing tumes predicted by the fraction of fresh water method.

\section{FLUSHING TIMES CALCULATED BY THE FRACTION OF}

FRESH WATER METHOD

\section{RIVER FLOW \\ $\left(10^{T} \mathrm{ft}^{3} /\right.$ tidal cycle $)$}

MAXIMUM SALINITY

INTRUSION

(nautical miles)
TOTAL

FLUSHING TIME

(tidal cycles)
549

684

755

1710
19

19

19

14
4. 87

3.91

3.54

0.90 